\begin{tabular}{c}
\hline JCEBT, 1 (1) Maret 2017 ISSN 2549-6379 (Print) ISSN 2549-6387 (Online) \\
JCEBT \\
ONournal of Civil Engineering, Building and Transportation) \\
Available online http://ojs.uma.ac.id/index.php/jcebt \\
\hline
\end{tabular}

\title{
Pengaruh Pemadatan Campuran Beton Terhadap Kuat Tekan K 175
}

\section{Effect of Compacting Concrete Combination Against Strong Press $\mathrm{K} 175$}

\author{
Wahyudi, Irwan*, Nurmaidah \\ Program StudiTeknik Sipil, FakultasTeknik, Universitas Medan Area, Indonesia \\ *Coresponding Email: irwan@gmail.com
}

\begin{abstract}
Abstrak
Tujuan penelitian ini dilakukan adalah untuk mengetahui mutu beton yang terbaik dari berbagai proses pemadatan yang akan di coba dengan nilai FAS yang sama dengan mutu beton K-175. Perbandingan mutu beton K-175 menggunakan bahan-bahan seperti semen, kerikil, pasir dan air. Faktor Air Semen (FAS) yang dipakai 0,60 dan bahan-bahan yang akan digunakan berasal dari Kota Binjai ,provinsi Sumatera Utara. Sehingga dalam aplikasi di lapangan perlu diperhatikan proses pemadatan yang tepat dan memberikan kekuatan tekan yang paling maksimal terhadap beton. Proses pemadatan yang akan diuji adalah proses pemadatan dengan cara dituang (tanpa pemadatan), proses pemadatan beton dengan cara di rojok dan proses pemadatan beton dengan meja getar. Benda uji pada penelitian ini adalah slinder beton dengan ukuran $\theta 15 \mathrm{~cm}$ dimensi $30 \mathrm{~cm}$ berjumlah 30 sampel .Setelah pengujian dilakukan, didapat perbandingan kuat tekan yang berbeda pada setiap percobaan maka beton yang tanpa pemadatan mempunyai kuat tekan rata-rata sebesar $9,96 \mathrm{~N} / \mathrm{mm}^{2}$, beton dengan pemadatan dirojok kuat tekan rata-rata $24,18 \mathrm{~N} / \mathrm{mm}^{2}$ dan beton dengan pemadatan dengan meja getar kuat tekan rata-rata $21,97 \mathrm{~N} / \mathrm{mm}^{2}$.pemadatan yang menghasilkan kuat tekan terbaik adalah pemadatan dengan dirojok.
\end{abstract}

Kata Kunci: Kuat Tekan Beton, Pemadatan Beton, Slump.

\begin{abstract}
The purpose of this research is to know the best quality of concrete from various compaction process which will be tested with the same FAS value with the quality of K-175 concrete. The quality comparison of K-175 concrete uses materials such as cement, gravel, sand and water. Cement Water Factor (FAS) used 0.60 and the materials to be used are from Binjai City, North Sumatera Province. So in the application in the field to note the proper compaction process and provide maximum compressive strength to the concrete. The compaction process to be tested is the compaction process by pouring (without compaction), concrete compaction process by way of rojok and concrete compaction process with vibrating table. The test specimens in this research are concrete slinder with size $\theta 15 \mathrm{~cm}$ dimension $30 \mathrm{~cm}$ totaling 30 samples. After the test is done, there is a different compressive strength ratio in each experiment, the concrete without compaction has an average compressive strength of $9,96 \mathrm{~N} / \mathrm{mm}^{2}$, concrete with solid compression is pressed on average $24.18 \mathrm{~N} / \mathrm{mm}^{2}$ and concrete with compacting with a compressive strength-shaking table averaging $21.97 \mathrm{~N} / \mathrm{mm}^{2}$.the compaction that produces the best compressive strength is the compaction with the dirojok.
\end{abstract}

Keywords: Strong Concrete Press, Concrete Compaction, Slump.

How to Cite: Wahyudi, Irwan, \& Nurmaidah. (2017). Pengaruh Pemadatan Campuran Beton Terhadap Kuat Tekan K 175. JCEBT (Journal of Civil Engineering, Building and Transportation). 1 (1): 37-53. 


\section{PENDAHULUAN}

Beton merupakan salah satu pendukung penting bangunan (konstruksi) yang terdiri dari campuran agregat, semen dan air. Penggunaan beton dan beton bertulang sebagai bahan konstruksi bangunan dewasa ini tidak terlepas dari sifat beton yang banyak menguntungkan, terutama karena kekuatan beton yang dapat di andalkan, serta konstruksi tersebut dapat dibuat sesuai dengan keinginan perencana.Dengan berkembang pesatnya teknologi beton pada akhir-akhir ini maka beton merupakan material konstruksi yang sangat bersaing terutama untuk struktur bangunan bertingkat, jalan dan jembatan, dermaga serta bangunan bendung dan irigasi. Dalam hal proses pembuatan adukan atau campuran beton sangat diperlukan perhatian pengendalian mutu beton.

Pemadatan beton segar merupakan salah satu proses dalam tahapan pengecoran beton yang memiliki pengaruh signifikan pada kekuatan beton sebagai hasil akhir dari pengecoran. Dalam proses pemadatan ini secara umum terdapat dua metode pemadatan yaitu pemadatan dalam dan pemadatan luar. Kedua metode pemadatan memiliki cara penggunaan yang berbeda namun memiliki tujuan yang sama yaitu untuk memadatkan beton segar dengan kepadatan yang optimal. Penelitian ini dilakukan berdasarkan Standar Nasional Indonesia (SNI) dan American Society of Civil Engineers (ASCE) dengan tujuan untuk mengetahui pengaruh tiga metode pemadatan beton segar terhadap kuat tekan beton dan segregasi beton yang mungkin terjadi.

Permasalahan yang dibahas dalam penelitian ini adalah bagaimana pengaruh metode pemadatan terhadap kuat tekan beton dan paling efektif dalam pencapaian kuat tekan beton serta dampak segregasi terkecil yang mungkin terjadi. Adapun maksud penelitian ini untuk menganalisa pengaruh proses pemadatan tekan. Tujuan dari penelitian ini dilakukan adalah untuk mengetahui mutu beton yang terbaik dari berbagai cara pemadatan yang akan di coba dengan proses pemadatan yang sama dengan mutu beton rencana K-175. Perbandingan mutu beton K-175 menggunakan bahan-bahan seperti semen, kerikil/Split, Pasir dan Air dan bahanbahan yang akan digunakan berasal dari daerah Binjai di Provinsi Sumatera Utara, sehingga dalam aplikasi di lapangan perlu diperhatikan proses pemadatan yang tepat dan memberikan kekuatan tekan yang paling maksimal terhadap beton

\section{METODE PENELITIAN}

Penelitian ini menggunakan sampel berjumlah 30 buah yang didistribusikan 
dalam beberapa kelompok perlakuan dan pengujian sesuai dengan prosedur dan kebutuhan sampel pada masing-masing metode pemadatan. Sampel dicetak menggunakan mutu beton K-175 (fc'=17,5 $\mathrm{MPa}$ ) sesuai dengan ketentuan SNI 032834-2002 yang kemudian dilakukan pemadatan dengan menggunakan tiga metode pemadatan :

1. Tanpa dipadatkan

2. Pemadatan beton dengan cara di rojok

3. Pemadatan beton dengan meja getar

Penelitian ini merupakan gabungan antara studi eksperimental dan kajian literatur. Tujuan studi eksperimental ini untuk meneliti pengaruh dari perlakuan pemadatan beton berdasarkan landasanteori dan literatur yang berkaitan dengan topik yang diteliti. Studi eksperimental dilakukan dengan pengujian kuat tekan pada umur 28 hari dan pengamatan visual terhadap segregasi beton.

\section{Gradasi Agregat}

Gradasi agregat sangat mempengaruhi kepadatan beton. Untuk menghasilkan beton yang padat, diantaranya butiran agragat harus bervariasi dari ukuran yang paling kecil hingga yang paling besar. Untuk mendapatkan mendapatkan campuran beton yang padat kadang-kadang kita harus mencampur beberapa jenis agregat.Dalam pekerjaan beton yang banyak dipakai adalah agregat normal dengan gradasi yang harus memenuhi syarat standar.

Syarat susunan butiran agregat untuk beton sudah diatur dalam SK-SNI T-151990-03, atau standar asing lainnya seperti ASTM dan British standart (BS). Menurut standar-standar tersebut, maka gradasi agregat harus memenuhi syarat sebagai berikut: Persyaratan gradasi agregat halus SK-SNI T-15-1990-03 memberikan syarat-syarat untuk agregat halus yang diadopsi dari British standart. Agregat halus

\section{Kadar Air}

Kadar air adalah banyaknya air yang terkandung dalam suatu agregat.Kadar air pada agregat berbeda sesuai dengan kondisi agregatnya.kadar air agregat dapat di bedakan menjadi empat jenis :

1. Kadar air kering tungku, Yaitu keadaan yang benar-benar tidak berair

2. Kadar air kering udara, Yaitu kondisi agregat yang permukaannya kering tetapi sedikit mengandung air di dalam porinya dan masih dapat menyerap air.

3. Kondisi jenuh kering permukaan (JPK), Yaitu keadaan dimana tidak ada air di permukaan agregat tetapi agregat tersebut masih mampu menyerap air. 
Pada kondisi ini, air dalam agregat tidak akan menambah atau mengurangi air pada campuran beton.

4. Kondisi basah, Yaitu kondisi dimana butir-butir agregat banyak mengandung air, sehinga akan menyebabkan penambahan kadar air dalam campuran beton.

\section{Berat Jenis dan Daya Serap Agregat}

Berat jenis digunakan untuk menentukan volume yang diisi oleh agregat. Berat jenis dari agregat pada akhirnya akan menentukan berat jenis dari beton sehingga secara langsung menentukan banyaknya campuran agregat dalam campuran beton. Hubungan antara berat jenis dan daya serap adalah jika semakin tinggi nilai berat jenis agregat maka semakin kecil daya serap air agregat tersebut.

Pemeriksaan Mutu Agregat dan Syarat Mutu Agregat

Pemeriksaan mutu agregat dimaksudkan untuk mendapatkan bahanbahan campuran beton yang memenuhi syarat.Sehingga beton yang dihasilkan nantinya sesuai dengan yang diharapkan.Jika dilihat dari volume agregat dalam campuran beton, agregat memberikan kontribusi yang besar terhadap campuran.
1. Agregat normal menurut SII.0052

2. Agregat Halus

3. Modulus halus butir 1.5 sampai 3.8

4. Kadar lumpur atau bagian yang lebih kecil dari 70 mikron $(0.074 \mathrm{~mm})$ maksimum 5\%

Kadar zat organik yang terkandung yang ditentukan dengan mencampur agregat halus dengan larutan natrium sulfat (NaSO4) 3\%, jika dibandingkan dengan warna standar/ pembanding tidak lebih tua dari pada warna standar.

Kekekalan (jika diuji dengan natrium sulfat bagian yang hancur maksimum 10\%, dan jika di pakai magnesium sulfat, maksimum 15\%).

\section{Agregat Kasar}

Modulus halus butir 6.0 sampai 7.1. Kadar lumpur atau bagian yang lebih kecil dari 70 mikron $(0.074 \mathrm{~mm})$ maksimum 1\%.Kadar bagian yang lemah jika diuji dengan goresan batang tembaga maksimum 5\%.Kekekalan jika diuji dengan natrium sulfat bagian yang hancur maksimum 12\%, dan jika dipakai magnesium sulfat bagian yang hancur maksimum 18\%. Tidak bersifat reaktif terhadap alkali jika kadar alkali dalam semen sebagai Na20 lebih besar dari 0.6\%.

Tidak mengandung butiran yang panjang dan pipih lebih dari 20\%. Kekerasan agregat harus memenuhi syarat 
seperti Tabel 2.2 di atas.Agregat normal menurut ASTM C.33.Agregat normal yang dipakai dalam campuran beton sesuai dengan ASTM, berat isinya tidak boleh kurang dari $1200 \mathrm{~kg} / \mathrm{m} 3$.

\section{Agregat Halus}

Modulus halus butir 2.3 sampai 3.1. Kadar lumpur atau bagian yang lebih kecil dari 70 mikron (0.074 $\mathrm{mm}$ atau No.200) dalam persen berat maksimum, Untuk beton yang mengalami abrasi sebesar $3.0 \%$

Untuk beton jenis lainnya sebesar 5\%.Kadar gumpalan tanah liat dan partikel yang mudah dirapikan maksimum 3\%.

Kandungan arang dan lignit, Bila tampak permukaan beton dipandang penting, maksimum 0.5\%. Beton jenis lainnya, maksimum $1.0 \%$.

Kadar zat organik yang ditentukan dengan mencampur agregat halus dengan larutan natrium sulfat (NaSO4) 3\%, tidak menghasilkan warna yang lebih tua disbanding warna standar. Jika warnanya lebih tua maka ditolak kecuali, Warna lebih tua timbul karena sedikit adanya arang lignit atau yang sejenis.

Ketika duji dengan uji perbandingan kuat tekan beton yang dibuat dengan pasir standar silika hasilnya menunjukkan nilai lebih besar dari 95\%.
Tidak boleh bersifat reaktif terhadap alkali jika dipakai untuk beton yang berhubungan dengan basah dan lembab atau yang berhubungan dengan bahan yang bersifat rekatif terhadap alkali semen, dimana penggunaan semen yang mengandung natrium oksida tidak lebih dari $0.6 \%$.

Kekekalan jika diuji dengan natrium sulfat bagian yang hancur maksimum $10 \%$, dan jika dipakai magnesium sulfat, maksimum 15\%. Susunan gradasi harus memenuhi syarat.

\section{Agregat Kasar}

Tidak boleh bersifat reaktif terhadap alkali jika dipakai untuk beton yang berhubungan dengan basah dan lembab atau yang berhubungan dengan bahan yang bersifat reaktif terhadap alkali semen, dimana penggunaan semen yang mengandung natrium oksida tidak lebih dari $\quad 0.6 \%$.Susunan gradasi harus memenuhi syarat. Kadar bahan atau partikel yang berpengaruh buruk pada beton.

Sifat fisika yang mencakup kekerasan agregat diuji dengan bejana Los Agelos dan sifat kekal.batas ijin parf" ' 37 yang berpengaruh buruk terhadap beton dan sifat fisika yang diijinkan untuk agregat kasar. 
Air

Air diperlukan pada pembuatan beton untuk memicu proses kimiawi semen, membasahi agregat dan memberikan kemudahan dalam pengerjaan beton. Air yang dapat diminum umumnya dapat digunakan sebagai campuran beton. Air yang mengandung senyawa-senyawa yang berbahaya, yang tercemar air garam, minyak, gula, atau bahan-bahan kimia lainnya, bila dipakai dalam campuran beton akan menurunkan kualitas beton, bahkan dapat mengubah sifat-sifat beton yang dihasilkan.

Karena pasta semen merupakan hasil reaksi kimia antara semen dengan air, maka bukan perbandingan jumlah air terhadap total berat campuran yang penting, tetapi perbandingan air dengan semen atau yang biasa disebut sebagai Faktor Air Semen (water cement ratio). Air yang berlebihan akan menyebabkan banyaknya gelembung air setelah proses hidrasi selesai, sedangkan air yang terlalu sedikit akan menyebabkan proses hidrasi tidak tercapai seluruhnya, sehingga akan mempengaruhi kekuatan beton.

\section{Sumber-sumber Air}

Air yang digunakan dapat berupa air tawar (dari sungai, danau, telaga, kolam, situ dan lainnya), air lut maupun air limbah, asalkan memenuhi syarat mutu yang telah di tetapkan. Air tawar yang dapat diminum umumnya dapat digunakan untuk campuran beton. Sumber-sumber air yang ada (Tri mulyono,2004) adalah :

Air yang terdapat di udara, Air yang terdapat diudara atau atmosfir adalah air yang terdapat diawan.Kemurnian air ini sangat tinggi. Air yang terdapat dalam atmosfir kondisinya sama dengan air suling, sehingga sangat mungkin untuk mendapatkan beton yang baik dengan menggunakan air ini.

Air hujan, Air hujan menyerap gasgas serta uap dari udara ketika jatuh ke bumi, Biasanya air hujan mengandung unsur oksigen, nitrogen dan karbondioksida.

Air tanah, Terdiri dari unsure kation (seperti $\mathrm{Ca}++, \mathrm{Mg}++, \mathrm{Na}+$, dan $\mathrm{K}+$ ) dan unsur Anion pada kadar yang lebih rendah, Terdapat juga unsur Fe, Mn, Al, B, F dan Se. disamping itu air tanah juga menyerap gas-gas serta bahan-bahan organik seperti CO2, H2S, dan NH3.

Air permukaan, Air permukaan dibagi menjadi air sungai, air danau, situ, dan air genangan.Erosi yang disebabkan oleh aliran air permukaan, membawa serta bahan-bahan organic dan mineralmineral.Air sungai atau air danau dapat digunakan sebagai campuran beton, asal tidak tercemar oleh air buangan 
industri.Air rawa-rawa atau air genangan tidak dapat digunakan sebagai bahan campuran beton, kecuali setelah melalui pengujian kualitas air.

Air laut, Air laut mengandung 30.000$36.000 \mathrm{mg}$ garam per liter (3\%-3,6\%) pada umumnya dapat digunakan sebagai campuran untuk beton tidak bertulang, beton pra-tegang dan beton pra-tekan atau dengan kata lain untuk beton-beton mutu tinggi. Air laut tidak boleh digunakan pembuatan beton pra-tegang atau pratekan, karena batang-batang baja pratekan langsung berhubungan dengan betonnya. Air laut sebaliknya tidak digunakan untuk beton yang ditanami alumunium di dalamnya beton yang memakai tulangan atau yang mudah mengalami korosi pada tulangannya akibat perubahan panas (temperatur) dan lingkungan lembab. (ACI 318-89:2-2)

Tabel 1. Unsur-unsur kimia dalam air laut

\begin{tabular}{ll}
\hline Unsur Kimia & Kandungan (ppm) \\
\hline Clorida $(\mathrm{Cl})$ & 19.000 \\
Natrium $(\mathrm{Na})$ & 10.600 \\
Magnesium $(\mathrm{mg})$ & $\mathbf{1 . 2 7 0}$ \\
Sulfur $(\mathrm{S})$ & 880 \\
Calium $(\mathrm{Ca})$ & 400 \\
Kalsium $(\mathrm{K})$ & 380 \\
Brom $(\mathrm{Br})$ & 65 \\
Carbon $(\mathrm{C})$ & $\mathbf{2 8}$ \\
Cr & $\mathbf{1 3}$ \\
B & $\mathbf{4 , 6}$ \\
Sumber $:$ Concrete Technology and Practice
\end{tabular}

\section{Syarat Umum Air}

Air yang akan dipakai untuk membuat campuran beton dan juga untuk pemeliharaan beton yang telah mengeras harus memenuhi beberapa persyaratan sebagai berikut:

1. Air tawar yang dapat diminum. Air harus bersih dan tidak boleh mengandung minyak; asam alkali, garam-garam bahan-bahan organis atau bahan-bahan yang dapat merusak beton dan baja tulangan beton.

2. Air yang bereaksi netral terhadap lakmus. Air pencampur yang digunakan pada beton yang didalamnya tertanam logam aluminium termasuk air bebas yang terkandung dalam agregat, tidak boleh mengandung ion klorida dalam jumlah yang membahayakan.

3. Apabila terdapat keragu-raguan terhadap pemakaian air, dianjurkan untuk mengirim contoh air itu ke lembaga pemeriksaan air untuk diselidiki sampai seberapa jauh air itu mengandung zat-zat yang dapat merusak beton/baja tulangan.

\section{Pemilihan Pemakaian Air}

Pemilihan air yang digunakan sebagai campuran beton didasarkan pada campuran beton. Air tersebut harus berasal dari sumber yang sama dan terbukti menghasilkan beton yang memenuhi syarat. Jika air yang ada dari sumber belum terbukti memenuhi syarat, 
harus dilakukan uji tekan mortar yang dibuat dengan air tersebut, yang kemudian dibandingkan dengan campuran mortar yang menggunakan air suling.

Syarat mutu air menurut British Standart (BS.3148-80). Berikut adalah criteria yang harus dipenuhi oleh air yang akan digunakan sebagai campuran beton. Jika ketentuan ketentuan dibawah ini tidak terpenuhi, Sebaiknya air tidak digunakan untuk membuat campuran beton. Syaratsyarat tersebut antara lain adalah (Tri mulyono, 2004) :

Garam-garam Anorganik, Ion-ion utama yang terdapat dalam air adalah kalsium, magnesium, natrium, kalium, bikarbonat, sulfat, klorida, nitrat, dan karbonat. Gabungan ion-ion tersebut tidak boleh lebih besar dari $2000 \mathrm{mg}$ per liter.garam-garam anorganik ini akan memperlambat waktu pengikatan beton dan menyebabkan menurunnya kekuatan beton. Konsentrasi garam-garam tersebut hingga 500 ppm dalam campuran beton masih diijinkan.

NaCI dan Sulfat, Konsentrasi NaCL atau garam dapur sebesar 20000 ppm pada umumnya masih diijinkan. Air campuran beton mengandung $1250 \mathrm{ppm}$ natrium sulfat, Na2SO4.10 H2O, dapat digunakan dengan hasil yang memuaskan. Air asam, Air campuran asam dapat digunakan atau tidak berdasarkan konsentrasi asamnya yang dinyatakan dalam ppm (Parts per million) .Bisa atau tidaknya air ini digunakan ditentukan berdasarkan nilah $\mathrm{pH}$. Air netral biasanya mempunyai $\mathrm{pH}$ sekitar 7.00.nilai $\mathrm{pH}$ diatas 7.00 menyatakan keadaan kebasaan dan nilai $\mathrm{pH}$ Menyatakan nilai keasaman. Semakin tinggi nilai asam $(\mathrm{pH}>3.00)$, semakin sulit kita mengelola pekerjaan beton.Karena itu penggunaan air dengan pH diatas 3.00 harus dihindarkan.

Air basa, Air dngan kandungan natrium hidroksida sekitar $0.5 \%$ dari berat semen, tidak banyak berpengaruh pada kekuatan beton, asalkan waktu pengikatan tidak berlangsung dengan cepat. Konsentrasi bias lebih tinggi dari 0.5\% berat semen akan mempengaruhi kekuatan beton.

Air gula, Apabila kadar gula dalam campuran dinaikkan hingga mencapai $0.2 \%$ dari berat semen, maka waktu pengikatan biasanya akan semakin cepat. Gula sebanyak $0.25 \%$ berat semen atau lebih akan mengakibatkan bertambah cepatnya waktu pengikatan secara signifikan dan berkurangnya kekuatan beton pada umur 28 hari.

Minyak, Minyak mineral atau minyak tanah dengan kosentrasi lebih dari $2 \%$ berat semen dapat mengurangi kekuatan beton hingga 20\%.Karena itu penggunaan air yang tercemar minyak 
sebaiknya dihindari.Rumput laut, Rumput laut yang tercampur dalam air campuran beton dapat menyebabkan berkurangnya kekuatan beton secara signifikan. Bercampurnya rumput laut dengan semen akan mengakibatkan berkurangnya daya lekat dan menimbulkan terjadinya sangat banyak gelembung-gelembung udara dalam beton. Beton menjadi keropos dan pada akhirnya kekuatannya akan berkurang. Rumput laut dapat juga dijumpai dalam agregat terutama jika agregat yang digunakan adalah agregat halus dari pasir pantai.Hal itu membuat hubungan antara agregat dan pasta semen terganggu, bahkan menjadi buruk.

Zat-zat Organik, Lanau dan Bahanbahan Terapung, Kandungan zat organik dalam air dapat mempengaruhi waktu pengikatan semen dan kekuatan beton. Air yang berwarna tua, berbau tidak sedap dan mengandung butir-butir lumut perlu diragukan dan harus diuji sebelum dipakai.Kira-kira 2000 ppm lempung yang terapung atau bahan-bahan halus yang berasal dari batuan diijinkan ada dalam campuran. Untuk mengurangi kadar lanau dan lempung dalam adukan beton, yang mengandung lumpur harus diendapkan terlebih dahulu dalam bak-bak penampung sebelum digunakan.

Pencemaran limbah Industri atau air limbah, Air yang tercemar limbah industri sebelum dipakai harus dianalisis kandungan pengotornya dan diuji (dengan percobaan perbandingan) untuk mengetahui pengikatannya dan kekuatan tekan betonnya.Air limbah biasanya mengandung $400 \quad \mathrm{ppm}$ senyawa organic.Setelah air limbah itu disaring ditempat yang cocok untuk keperluan pencampuran beton, konsentrasi senyawa organik biasanya turun menjadi $20 \mathrm{ppm}$ atau kurang dari itu.Jadi, setelah disaring, barulah air limbah dapat digunakan.

\section{Syarat Kimia Air}

Air yang mengandung kotoran yang cukup banyak akan mengganggu proses pengerasan atau ketahanan beton. Kandungan kurang dari 1000 ppm (parts per million) msaih diperbolehkan meskipun konsentrasi lebih dari 200 ppm sebaiknya dihindari. Pada BS 3148 terdapat dua metode untuk menilai kelayakan air untuk campuran beton, yaitu dengan membandingkan waktu pengikatannya dan kuat tekan benda uji yang dibuat dengan semen dan air.air suling dianggap memenuhi syarat jika tidak berubah waktu pengikatannya lebih dari 30 menit, atau berkurang kekuatannya dengan lebih dari 20\% dibandingkan air suling.

Bila masih diragukan, adakan perbandingan antara mortar yang 
memakai air tersebut dengan mortar yang memakai air suling/air tawar. Dipakai kubus mortar ukuran $50 \mathrm{~mm}$, sesuai SII 0013-81 atau ASTM C109. Kekuatan umur 7 dan 28 hari minimal 90\% dari kekuatan mortar dari air tawar. Namun sifat-sifat lain harus diperiksa, misalnya pengaruh jangka panjang.

\section{Nilai Slump}

Nilai slump adalah nilai yang diperoleh dari hasil uji slump dengan cara beton segar diisikan ke dalam suatu corong baja berupa kerucut terpancung, kemudian bejana ditarik ke atas sehingga beton segar meleleh ke bawah. Besar penurunan permukaan beton segar diukur, dan disebut nilai 'slump'. Makin besar nilai slump, maka beton segar makin encer dan ini berarti semakin mudah untuk dikerjakan.

Penetapan nilai slump dilakukan dengan mempertimbangkan faktor-faktor berikut:

1. Cara pengangkutan adukan beton.

2. Cara penuangan adukan beton.

3. Cara pemadatan beton segar.

\section{Jenis Struktur yang dibuat}

Cara pengangkutan adukan beton dengan aliran dalam pipa yang dipompa dengan tekanan membutuhkan nilai slump yang besar, adapun pemadatan adukan dengan alat getar (triller) dapat dilakukan dengan nilai slump yang sedikit lebih kecil.

\section{Pemadatan Beton (Vibrating)}

Pencampuran bahan-bahan penyusun beton dilakukan agar diperoleh suatu komposisi yang solid dari bahanbahan penyusun berdasarkan rancangan campuran beton.Agar tetap terjaga konsistensi rancangannya, tahapan lebih lanjut dalam pengolahan beton perlu diperhatikan. Tahapan pelaksanaan di lapangan meliputi :

1. Persiapan

2. Penakaran

3. Pengadukan (mixing)

4. Penuangan atau Pengecoran (Placing)

5. Pemadatan (Vibrating)

6. Penyelesaian Akhir (Finishing)

7. Perawatan (Curing)

Dalam penguraian pekerjaan beton hanya di uraikan adalah pemadatan (vibrating). Pemadatan dilakukan segera setelah beton dituang. Kebutuhan akan alat pemadat disesuaikan dengan kapasitas pengecoran dan tingkat kesulitan pengerjaan. Pemadatan dilakukan sebelum terjadinya setting time pada beton.

Untuk menghilangkan udara yang terdapat antara dinding dan spesi beton juga di dalam campuran beton itu sendiri dilakukan pemadatan. Karena kalau tidak 
dilakukan maka udara akan membentuk ruang kosong dalam beton. Ruang kosong itu sangat merugikan bagi kualitas beton, selain kekuatannya berkurang hasil cornya akan buruk dan berongga.

\section{Metode Pemadatan Beton}

Metode pedatan dengan cara di tuang yaitu dengan cara menuangkan benda uji kedalam bejana secara berlahan-lahan ,dengan jarak antara sekop dan bejana 5 cm. Metode pemadatan dengan cara di rojok yaitu dengan cara menusuk-nusuk dengan sepotong kayu atau batang lain

Metode pemdatan meja getar yaitu pemadatan dengan menggunakan alat mekanis yang di sebut meja getar.Pengambilan keputusan apakah telah atau belum cukup pemadatan yang dilakukan ialah dengan menggunakan indera penglihatan dan pendengaran.Untuk indera penglihatan dapat dilihat keluarnya gelembunggelembung udara yang besar kemudian disertai gelembung-gelembung yang kecil. Juga dapat dilihat pada permukaan beton akan mulai bersinar akibat cukupnya air akibat bleeding.

Pemadatan dimaksudkan untuk menghilangkan rongga-rongga udara yang terdapat dalam beton segar. Pada pengerjaan beton dengan kapasitas kecil, alat pemadat dapat berupa kayu atau besi
tulangan.Sedangkan adapun alat yang sering digunakan pada pengerjaan dengan volume besar yaitu vibrator atau alat getar. Pada pengerjaan beton dengan kapasitas kecil, alat pemadat dapat berupa kayu atau besi tulangan.Untuk pengecoran dengan kapasitas lebih besar dari $10 \mathrm{~m}^{3}$, alat pemadat mesin harus digunakan. Alat pemadat ini lebih dikenal dengan nama vibrator atau alat getar. Pemadatan dilakukan dengan penggetaran. Campuran beton akan mengalir dan memadat karena rongga-rongga akan terisi dengan butirbutir yang lebih halus. Alat getar ini dibagi menjadi dua, yaitu:

1. Alat getar intern (internal vibrator), yaitu alat getar yang berupa tongkat dan digerakan dengan mesin. Untuk menggunakannya, tongkat dimasukkan ke dalam beton pada waktu tertentu, tanpa harus menyebabkan bleeding.

2. Alat getar cetakan (external vibrator or form vibrator), yaitu alat getar yang mengetarkan form work sehingga betonnya bergetar dan memadat. Ada beberapa pedoman yang digunakan dalam proses pemadatan, antara lain:

a. Pada jarak yang berdekatan/pendek, pemadatan dengan alat getar dilaksanakan dalam waktu yang pendek. 
b. Pemadatan dilaksanakan secara vertikal dan jatuh dengan beratnya sendiri.

c. Tidak menyebabkan bleeding.

d. Pemadatan merata.

e. Tidak terjadi kontak antara alat getar dengan bekisting.

f. Alat getar tidak berfungsi untuk mengalirkan, mengangkut atau memindahkan beton.

Pemadatan yang tidak baik akan menyebabkan menurunnya kekuatan beton, karena tidak terjadinya pencampuran bahan yang homogeny. Pemadatan yang berlebih pun akan menyebabkan terjadinya bleeding. Pemadatan harus dilakukan sesuai dengan syarat mtu.Hal ini yang dapat dilakukan adalah melihat manual pemadat yang digunakan sehingga pemadatan pada campuran beton dapat dilakukan secara efisien dan efektif.

\section{HASIL DAN PEMBAHASAN}

Metode pengujian pada agregat, yaitu pada agregat kasar dan agregat halus dilakukan sesuai dengan standart pengujian yaitu sebagai berikut :

1. Berat jenis dan penyerapan air sesuai dengan SK SNI M 09 -1989 - F (agregat kasar ) dan SK SNI M 10-1989-F ( agregat halus).

2. Berat isi sesuai dengan ASTM C-91A-78
3. Analisa ayakan sesuai dengan SK SNI M 08-1989-F

4. Kadar lumpur sesuai dengan ASTM C 117-95

5. Organik impuritis sesuai dengan ASTM C 40-92

6. Kadar air sesuai dengan SK SNI M 111989-F

Setelah didapat sifat fisik agregat dan sifat fisik agregat tambahan dengan persyaratan yang sesuai dengan beton menurut SII No.0052-80. Persyaratan tersebut dapat dianalisa apakah agregat memenuhi syarat atau tidak .selanjutnya untuk mengetahui sifat fisik beton baik beton segar maupun beton keras maka dilakukan pengujian berdasarkan standar pengujian, sebagai berikut :

\section{Pengujian Terhadap Beton Segar}

Uji slump sesuai dengan SK SNI M-121989-F

Berat isi sesuai dengan ASTM C 138-92

\section{Pengujian terhadap beton keras}

kuat tekan sesuai dengan SK SNI M-141989-F

\section{Bahan-Bahan Penelitian}

Penelitian ini bahan - bahan material yang digunakan adalah :

3. Semen yang digunakan semen portland type 1.

4. Air yang digunakan adalah air mineral atau setara dengan air suling. 
5. Agregat halus yang digunakan dari toko material yang diambil dari daerah Kota Binjai di Propinsi Sumatera Utara. Agregat kasar yang digunkan dari toko material dengan ukuran $\leq 30 \mathrm{~mm}$ yang diambil dari daerah Kota Binjai di Propinsi Sumatera Utara.

\section{Koreksi Proporsi Campuran}

Apabila agregat tidak dalam keadaan jenuh kering permukaan (SSD), proporsi campuran harus dikoreksi terhadap kandungan dalam agregat. Koreksi proporsi campuran dilakukan terhadap kadar air dalam agregat minimum dan dihitung dengan rumus :

Air $=\mathrm{B}-(\mathrm{Ck}-\mathrm{Ca}) \times \mathrm{C} / 100-(\mathrm{Dk}-\mathrm{Da}) \mathrm{x}$ $\mathrm{D} / 100$

Agregat Halus $=\mathrm{C}+(\mathrm{Ck}-\mathrm{Ca}) \times \mathrm{C} / 100$

Agregat Kasar $=\mathrm{D}+(\mathrm{Dk}-\mathrm{Da}) \times \mathrm{D} / 100$

Kebutuhan agregat gabungan ditentukan dengan menggunakan rumus sebagai berikut :

$\mathrm{Bag}=\mathrm{BJb}-\mathrm{BS}-\mathrm{BA}$

Dimana :

$\mathrm{B}=$ jumlah Air $(\mathrm{kg} / \mathrm{m} 3)$

$\mathrm{C}=$ jumlah agregat halus $(\mathrm{kg} / \mathrm{m} 3)$

$\mathrm{D}=$ jumlah agregat kasar $(\mathrm{kg} / \mathrm{m} 3)$

$\mathrm{Ca}=$ absorbsi air pada agregat halus (\%)

$\mathrm{Da}=$ absorbsi air pada agregat kasar (\%)

$\mathrm{Ck}=$ kandungan air dalam agregat halus

$(\%)$
$\mathrm{Dk}=$ kandungan air dalam agregat kasar $(\%)$

Bag $=$ berat agregat beton

$\mathrm{BJb}=$ berat jenis beton

$\mathrm{BS}=$ berat semen

$\mathrm{BA}=$ berat air

\section{Prosedur Pengerjaan:}

Bahan :

1. beton segar yang sudah diaduk dan dicetak kedalam kubus

2. Prosedur pengujian :

3. Pembuatan benda uji

4. Siapkan cetakan dan beri pelumas

5. Masukkan beton segar dan dirojok sebanyak 25 kali sampai permukaan rata dan mengkilap

6. Simpan benda uji dalam cetakan selama 24 jam

7. Buka cetakan dan rendam benda uji sampai 28 hari

\section{Pemadatan dengan cara dituangkan}

1. Ambil sampel dengan menggunakan sekop, tuangkan kedalam bejana secara berlahan-lahan, jarak antara sekop dengan bejana $5 \mathrm{~cm}$

2. Pengisian dilakukan sampai bejana penuh dan diratakan

3. Lakukan percobaan ini sebanyak 3 kali. 4. 20 buah benda uji slinder 


\section{Pemadatan dengan cara dirojok}

1. Ambil sampel, masukkan kedalam $1 / 3$ dari tinggi bejana, lalu dirojok-rojok dengan menggunakan besi perojok sebanyak 25 kali.

2. Tambah sample $1 / 3$ bagian lagi sehingga $2 / 3$ bagian, lakukan kembali perojok sebanyak 25 kali dengan ketentuan tidak melewati bagian pertama.

3. Tambah $1 / 3$ sample rojok kembali sebanyak 25 kali, lalu tambah lagi sampai terisi penuh rojok 25 kali dan ratakan.

4. Ulangi percobaan ini sebanyak $3 \mathrm{kali}$.

5. 20 buah benda uji slinder

\section{Pemadatan Meggunakan Meja Getar}

1. Ambil sampel dengan menggunakan sekop, tuangkan kedalam bejana secara perlahan-lahan, jarak antara sekop dan bejana $5 \mathrm{~cm}$

2. Pengisian dilakukan sampai penuh dan ratakan.

3. Angkat sampel dan letakan di atas meja getar.

4. Hidupkan meja getar

5. Ketika sampel kurang tambahkan kedalam slinder

6. Tunggu sampai sampai benar-benar padat

7. 20 buah benda uji slinder

\section{Pengujian Kuat Tekan Beton (Press} test)

Pada pengujian beton dilakukannya pengujian kuat tekan. Hal ini adalah cara melakukan pengujian kuat tekan beton.

Tujuannya untuk menentukan besarnya kuat tekan yang dihasilkan oleh sesuatu campuran beton sesuai dengan yang direncanakan

Alat yang digunakan adalah mesin uji kuat tekan beton

Cara pengujian, beton yang telah di rawat selama 28 hari di angkat dan dikeringkan dan siap di uji tekan timbang setiap benda uji siapkan mesin tekan dan masukkan tiap-tiap benda uji dengan bergantian. Atur jarum petunjuk dengan angka nol. Jalankan mesin dan beton siap di uji tekan oleh mesin. Catat penunjuk jarum yang bergerak dan diketahuinya kuat tekan benda uji tersebut P maks (kN). Lakukan pemberhentian mesin dimana benda uji telah mencapai kuat tekannya. lakukan benda uji lainnya secar bergantian.

\section{Perhitungan adalah}

kuat tekan: $\tau \mathrm{tk}=\mathrm{P} \max : \llbracket \mathrm{kg} / \mathrm{cm}^{\wedge} 2$ atau

$\mathrm{N} / \mathrm{mm}^{\wedge} 2$ ]

kuat tekan rata-rata : $\tau$ bm $=(\Sigma \tau$ tk $) / \mathrm{N}$

\section{Nilai Slump}

Perhitungan nilai slump pada beton pada dasarnya percobaan sederhana untuk 
mengetahui workability beton segar sebelum diaplikasikan dalam pengecoran. Percobaan dilakukan menggunakan kerucut abrams yang berdiameter atas 10 $\mathrm{cm}$ dan berdiameter bawah $20 \mathrm{~cm}$. Penelitian mengacu pada SNI 1972 : 2008. Pada pengujian slump beton normal dan beton campuran tumbukan kaca direncanakan sebesar $16-18 \mathrm{~cm}$.

Tabel 2. Data hasil pengujian slump test beton

\begin{tabular}{ll}
\multicolumn{2}{c}{ normal } \\
\hline $\begin{array}{l}\text { Tinggi } \\
\text { sampel }\end{array}$ & $\begin{array}{l}\text { Nitiki } \\
\text { Slump } \\
(\mathrm{cm})\end{array}$ \\
\hline 1 & 16 \\
2 & 15 \\
3 & 18 \\
4 & 18 \\
5 & 17 \\
Rata-rata & 16,8 \\
\hline
\end{tabular}

(Sumber : Hasil penelitian)

\section{Pengujian Kuat Tekan Benda Uji Slinder}

Pengujian kuat tekan beton betujuan untuk mengetahui kuat tekan beton normal dengan karakteristik K 175 dengan beton campuran tumbukan kaca.Pada penelitian ini, pengujian kuat tekan dilakukan setelah 28 hari dari pembuatan benda uji.Pada dasarnya pengujian kuat tekan mengacu pada SNI 03 - 1974 - 1990 "Metode Pengujian Kuat Tekan Beton".Apabila sesuai prosedur maka dapat dibandingkan kuat tekan beton normal.

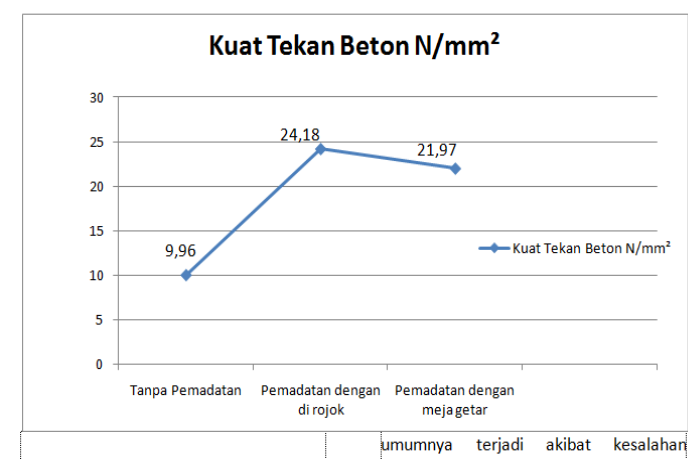

Gambar 1. Perbandingan hasil kuat tekan beton rata-rata

Dari hasil pengujian kuat tekan diperoleh hubungan rata-rata dari beton normal. Hasil dari kuat tekan rata-rata tanpa pemadatan sebesar $9,97 \mathrm{~N} / \mathrm{mm}^{2}$, kuat tekan rata-rata pemadatan dengan dirojok sebesar 24,18 $\mathrm{N} / \mathrm{mm}^{2}$ dan kuat tekan rata-rata pemadatan dengan meja getar sebesar 21,97 N/mm². Bahan-bahan material penyusun beton diperiksa dan dianalisa dengan baik sehingga perkiraan penetapan kuat tekan sedikit lebih besar dari yang direncakan. (Hasil Lampiran III, Data Pengujian).

\section{Hubungan Antara Porositas Terhadap Kuat Tekan Beton}

Secara teoritik hubungan atau korelasi antara porositas terhadap kuat tekan beton yaitu semakin besar porositas pada benda uji maka semakin rendah kekuatannya. Penelitian terhadap porositas lebih didasarkan dari segi keawetan dan kekuatan beton itu sendiri. Peningkatan persentase porositas 
memiliki keterkaitan terhadap penurunan kuat tekan maupun kuat tarik beton.

Porositas beton adalah tingkatan yang menggambarkan kepadatan konstruksi beton.Porositas ini berhubungan erat dengan permeabilitas beton.Porositas merupakan persentase pori-pori atau ruang kosong dalam beton terhadap volume benda (volume total beton). Ruang pori pada beton umumnya terjadi akibat kesalahan dalam pelaksanaan dan pengecoran seperti faktor air semen yang berpengaruh pada lekatan antara pasta semen dengan agregat, besar kecilnya nilai slump, pemilihan tipe susunan gradasi agregat gabungan, maupun terhadap lamanya pemadatan. Semakin tinggi tingkat kepadatan pada beton maka semakin besar kuat tekan atau mutu beton, sebaliknya semakin besar porositas beton, maka kekuatan beton akan semakin kecil.

Salah satu masalah yang sangat berpengaruh pada kuat tekan beton adalah adanya porositas.Porositas juga dapat diakibatkan adanya partikel-partikel bahan penyusun beton yang relatif besar, sehingga kerapatan tidak maksimal.Porositas beton juga menggambarkan besar kecilnya kekuatan beton dalam menyangga suatu konstruksi. Semakin padat beton, maka kekuatannya juga akan semakin besar sehingga dapat menyangga konstruksi yang lebih berat. Sebaliknya semakin renggang beton, maka kekuatannya juga akan semakin lemah sehingga hanya bisa menyangga konstruksi yang ringan dan ketahannannya juga tidak terlalu lama.

Meningkatnya nilai porositas menunjukkan bahwa beton memiliki pori yang cukup besar akibat terjadinya penguapan air dan pemuaian material pengisi beton. Hal ini merupakan salah satu penyebab turunya kualitas beton dalam memikul beban.

Porositas memiliki hubungan yang sangat erat dengan kekedapan dan keawetan beton. Beton yang memiliki nilai porositas minimum akan lebih awet dibandingkan dengan beton yang memiliki nilai porositas tinggi, karena porositas yang minimum akan memperkecil kemungkinan beton terkontaminasi oleh lingkungan luarnya terutama oleh lingkungan yang agresif.

Dalam pemadatan beton dengan cara dituang terlihat pori-pori yang ada dalam benda uji.

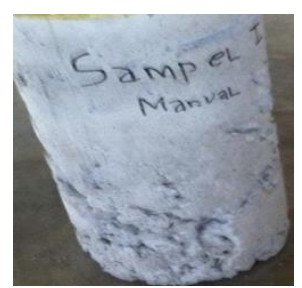

Gambar 2. Beton Dituang

Dalam pemadatan beton dengan dirojok ini pori yang ada di benda uji 
sangat kecil sehingga tidak terlalu terlihat oleh mata biasa

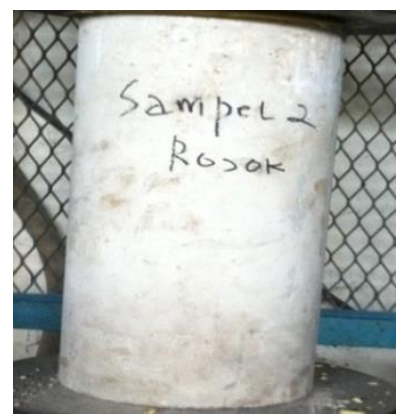

Gambar 3. Beton Dirojok

Dalam proses pemadatan beton dengan meja getar menghasil benda uji yang memiliki pori-pori yang rapat pada benda uji.

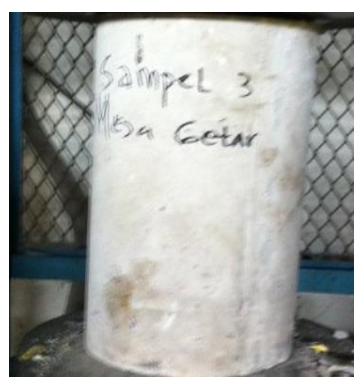

Gambar 4. Pemadatan Meja Getar

\section{SIMPULAN}

Sampel beton yang menghasilkan kuat tekan beton rata-rata paling tinggi adalah beton dengan cara di rojok dengan kuat tekan rata-rata $24,18 \mathrm{~N} / \mathrm{mm}^{2}$, makan sampel beton dengan cara dirojok cocok dipakai untuk pekerjaan beton yang membutuhkan hasil kuat tekan tinggi. Sampel beton dengan cara pemadatan menggunakan meja getar menghasilkan kuat tekan rata-rata $21,73 \mathrm{~N} / \mathrm{mm}^{2}$, disini beton dengan pemadatan dengan meja getar kehilangan kuat tekan sebesar 2,21
$\mathrm{N} / \mathrm{mm}^{2}$ bila dibandingkan dengan pemadatan beton dengan cara di rojok. Sampel beton tanpa pemadatan menghasilkan kuat tekan paling rendah yaitu rata-rata $9,96 \mathrm{~N} / \mathrm{mm}^{2}$,lebih tinggi bila dibandingkan dengan pemadatan dengan cara di rojok selisih kuat tekan sebesar $14,22 \mathrm{~N} / \mathrm{mm}^{2}$ terhadap beton dengan cara dirojok.

\section{DAFTAR PUSTAKA}

Anonim. (1989), SK SNI M-08-1989, Analisa Ayakan Agregat, LPMB, Bandung.

Anonim. (1989), SK SNI M-10-1989, Berat Jenis dan Penyerapan Agregat, LPMB, Bandung.

Anonim. (1989), SK SNI M-11-1989, Kadar Air Pada Agregat, LPMB, Bandung.

Anonim. (1989), SK SNI M-12-1989, Uji Slump, LPMB, Bandung.

Anonim. (1989), SK SNI M-14-1989, Kuat Tekan Beton, LPMB, Bandung.

Anonim. (1992), ASTM C40-92, Test Method For Organic Impurities Aggregates For Concrete.

Anonim. (2002), SK SNI 03-2874-2002, Tata Cara Perhitungan Struktur Beton Bertulang untuk Bangunan Gedung (Beta Version), Jakarta.

Anonim. (2006), Buku Penuntun Praktikum Beton. Fakultas Teknik, Jurusan Teknik Sipil Universitas Medan Area.

Mulyono, T. (2006), Teknologi Beton, Penerbit Andi, Yogyakarta.

Samekto, W. (2001), Teknologi beton, Penerbit Kansius, Yogyakarta.

Tjokrodimuljo, K. (1992). Teknologi Beton, Buku Ajar, Jurusan Teknik Sipil, Fakultas Teknik, Universitas Gajah Mada.

Vis, W.C. dan Kusuma G.H. (1993). Dasar-dasar Perencanaan Beton Bertulang, Seri Beton I, Penerbit Erlangga, Jakarta. 